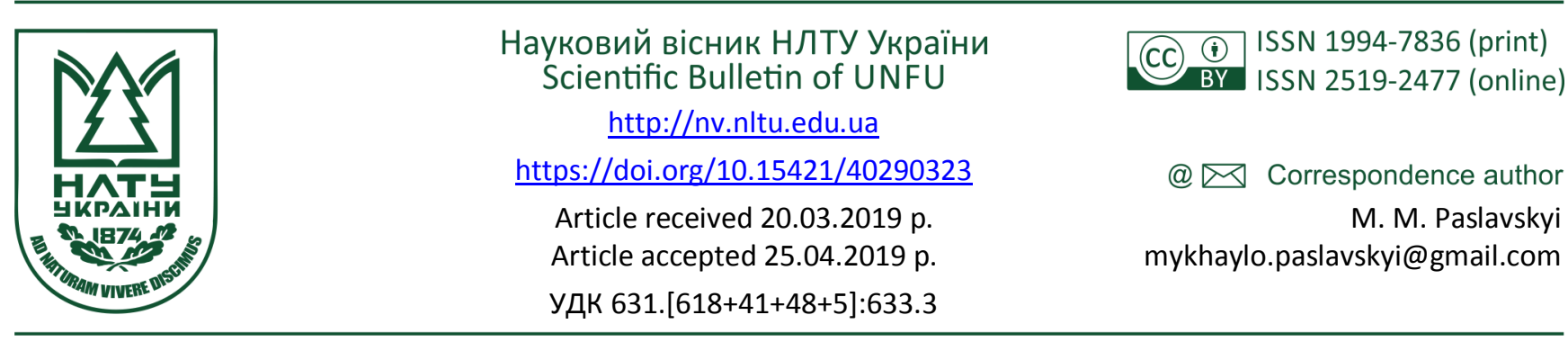

Т. Г. Бойко1, М. М. Паславський², М. В. Руда 1

${ }^{1}$ Національний університет "Львівська політехніка", м. Львів, Україна

${ }^{2}$ Національний лісотехнічний університет України, м. Львів, Украӥна

\title{
СТІЙКІСТЬ СКЛАДНИХ ЛАНДШАФТНИХ КОМПЛЕКСІВ: ФОРМАЛІЗАЦІЯ МОДЕЛІ
}

Визначено поняття "стійкості" для складного ландшафтного комплексу. Описано логічною послідовністю процес розвитку небезпеки у складному ландшафтному комплексі. Розроблено систему критеріїв, в основі якої, є зведення в чотири впорядкованих групи великої кількості антропогенних впливів на біоту. Антропогенні впливи поділяють відповідно 3 чотирма рівнями порушень біоти. Більшість традиційних токсичних ефектів (збільшення смертності, порушення онтогенезу та патології органів і т.ін.) потрапляе в групу, відповідну до рівня індивідуальних і популяційних відгуків (рівень 1). Ще одна група порушень та змін таких параметрів, як зміна первинної продуктивності; зміна агрегованих показників біомаси; зміна концентрації хлорофілу у лісовій екосистемі, інші системні порушення пов'язані з накопиченням важких металів та радіонуклідів (рівень 2). Дуже важливі і поки недостатньо охарактеризовані порушення відносяться до рівня стійкості та цілісності екосистем (рівень 3). Завершує цю систему група порушень вкладу екосистем в біосферні процеси (рівень 4), зокрема $\mathrm{i}$ в біогеохімічні потоки елементів. Розроблений підхід корисний під час розроблення максимально адекватної системи критеріїв і пріоритетів для оцінки і класифікації екологічної небезпеки антропогенних впливів зокрема екологічної небезпеки забруднювальних речовин. У запропонованій системі аналізу екологічної небезпеки належне місце займає небезпека впливу на стійкість і цілісність екосистеми, прикладом якої може слугувати небезпека ослаблення зв'язку між біотичними компонентами складного ландшафтного комплексу та абіотичними чинниками навколишнього середовища. Наведено опис лісової екосистеми враховуючи концепцію рівнеблокового підходу до аналізу екологічних небезпек антропогенного порушення біоти.

Ключові слова: стійкість; ландшафтний комплекс; модель; компартмент; множина; система.

Вступ. Унаслідок взаємодії природних компонентів і антропогенних чинників формується специфічна система складних ландшафтних комплексів (СЛК) різноманітного таксономічного рангу. Цій системі характерні структурно-функціональна єдність взаємозв'язаних компонентів і цілісність біотичної та абіотичної складових. Біотична складова навколишнього середовища об'єднується у компартменти, що складаються 3 ієрархічно пов'язаних між собою підсистем різних рівнів організації і великої кількості різноманітних ярусів, між якими існують тісні матеріально-енергетичні та ієрархічні зв'язки.

Серед різноманіття антропогенних впливів на СЛК (Flerov, 1989; Bezel, Bolshakov \& Vorobejnik, 1994; Yablokov \& Ostroumov, 1991) виділяють найважливіші показники та критерії, які характеризують негативний вплив антропогенних чинників (Krivoluckij, 1994) i xiмічних речовин (Ostroumov, 1986; Filenko, 1988; Malahov \& Medvedeva, 1991). Критерії для визначення екологічної небезпеки речовин розроблялися в площині оцінки токсичного забруднення екосистем ( $\mathrm{Li}$ et al., 2008). Для моделювання складних багатокомпонентних (багатовидових) екологічних систем потрібно створити модель стійкості. Математичну модель стійкості СЛК можна визначити як будь-яке спрощене відображення об'єкта (реального чи уявного). 3 огляду на масштаб досліджуваного СЛК такий підхід видається особливо актуальним. Проте для адекватного його використання необхідно чітко ранжувати небезпеки, що впливають на екологічні процеси в СЛК та розглядати той набір властивостей, що достатньо характеризує систему з точки зору поставленої мети дослідження.

Мета роботи - визначити модель стійкості для складних ландшафтних комплексів шляхом формалізації моделі компартмента досліджуваної системи.

Формалізація моделі. Компартмент СЛК $F$ можна подати як множину підмножин характеристик і записати у вигляді (рисунок).

$$
\boldsymbol{F}_{j i}=\left(G_{i}, T_{j}, S_{p}, I\right)
$$

де: $G$ - підмножина гігротопів $\boldsymbol{G}=\left\{G_{i} \mid i=1,5\right\} ; T$ - підмножина трофотопів $T=\left\{T_{j} \mid j=1,5\right\} ; S_{p}$ - множина видової різноманітності компартмента; $I$ - множина інтегральних характеристик, до яких можна віднести стій-

Інформація про авторів:

Бойко Тарас Георгійович, д-р техн. наук, професор, кафедра приладів точної механіки. Email: tgbo@ukr.net; https://orcid.org/0000-0002-0487-3293

Паславський Михайло Михайлович, пров. інженер, кафедра екологіï. Email: mykhaylo.paslavskyi@gmail.com; https://orcid.org/0000-0003-1635-4340

Руда Марія Віталіївна, канд. техн. наук, асистент, кафедра екологічної безпеки та природоохоронної діяльності. Email: marichkarmv@gmail.com; https://orcid.org/0000-0003-0590-4589

Цитування за Дсту: Бойко Т. Г., Паславський М. М., Руда М. В. Стійкість складних ландшафтних комплексів: формалізація моделі. Науковий вісник НЛтУ України. 2019, т. 29, № 3. С. 108-113.

Citation APA: Bojko, T. Gh., Paslavskyi, M. M., \& Ruda, M. V. (2019). Stability of composite landscape complexes: model formalization. Scientific Bulletin of UNFU, 29(3), 108-113. https://doi.org/10.15421/40290323 
кість СЛК. Остання множина характеристик також може включати зв'язки між компонентами екосистеми (Telitchenko \& Ostroumov, 1990; Ruda, Paslavskyi \& Taras, 2018).

Множина $G$ містить 5 елементів, або інакше кажучи, лісові типологи (Obshta et al., 2018). Виділяють 5 видів гігротопів: сухий, свіжий, вологий, сирий, мокрий. 3 кожним елементом пов'язують параметр $W$, який визначає середньорічну глибину рівня грунтових вод (у метрах).

Під час дослідження певної системи потрібно локалізувати місцевість, де проводяться дослідження, та ретельно стежити за основними параметрами. Множина $T$ містить 4 елементи - різновиди фофотопів: бір, субір, суфудок (судіброва), фуд (діброва), які характеризуються агрофізичними та агрохімічними парамефами. До таких властивостей передусім відносять множину фунтових характеристик $\boldsymbol{S}$ :

$$
\boldsymbol{S}=\{S p, S t, T D\},
$$

де: $S p$ - агрофізичні властивості; $S t$ - тип грунту; $T D$ лісова підстилка, виділена в окремий шар, оскільки розміщена на поверхні грунту.

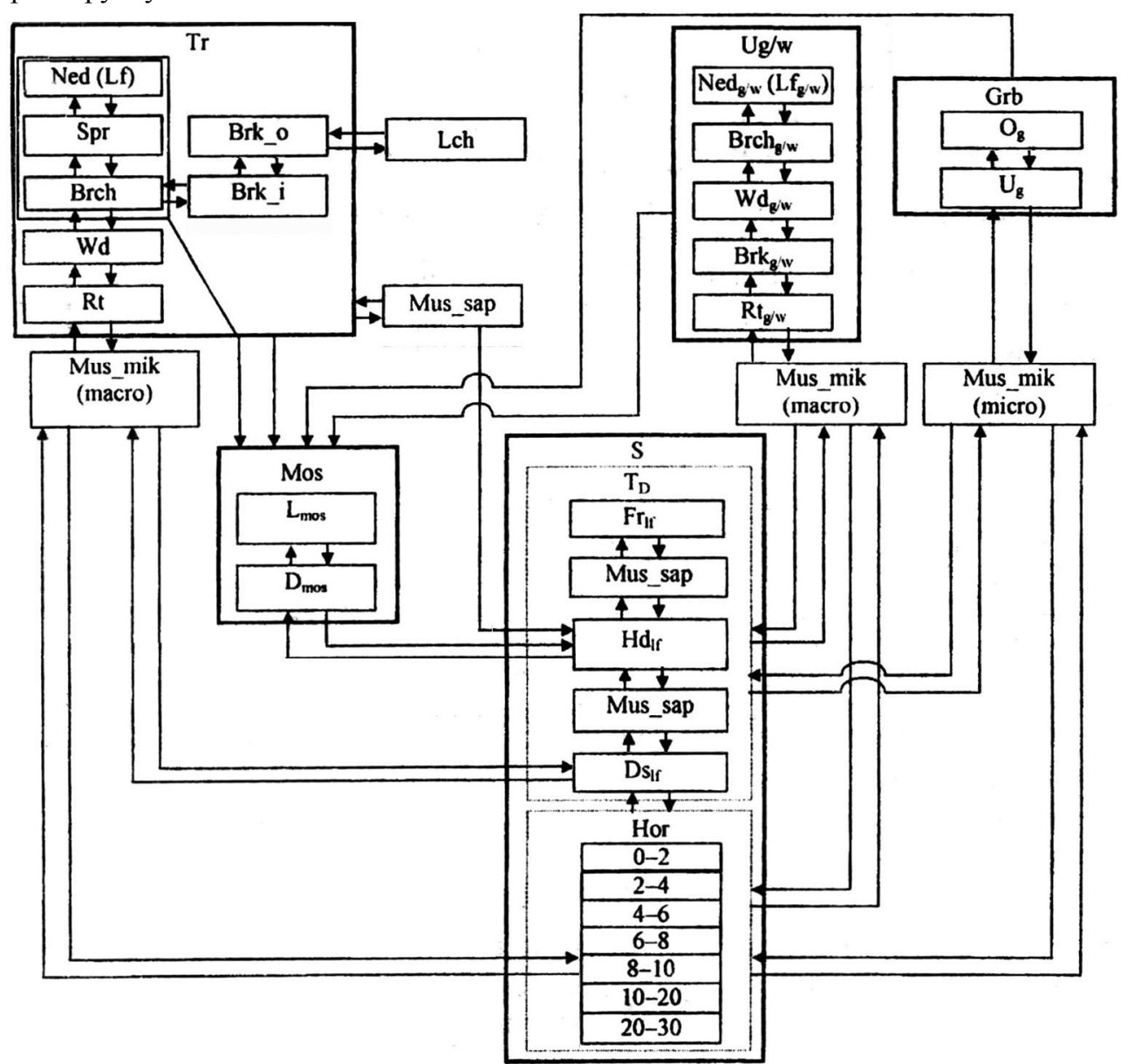

Рисунок. Концептуальна схема формалізованої моделі компартменту СЛК та зв'язків, що в ньому виникають

У грунтах СЛК прийнято виділяти такі елементи множини горизонтів (Obshta et al., 2018):

$$
\text { Hor }=\left\{B_{\text {hor }}, A_{\text {hor }}, A d\right\},
$$

де: $B_{h o r}-$ основні горизонти; $A_{\text {hor }}$ - додаткові горизонти; $A d$ - додаткові, відносно відокремлені, морфологічні елементи грунту.

$$
\boldsymbol{B}_{\text {hor }}=\{T, H o, H, E, I, P\},
$$

де: $T$ - торф'яні, що складаються з рослинних решток 3 різним ступенем розкладу; Но - органічні акумулятивні, лісова підстилка; $H$ - гумусові горизонти, які акуму-
Агрофізичні властивості характеризують грунт 3 точки зору фізичних особливостей твердої речовини. Тому множину характеристик можна записати у такому вигляді:

$$
\boldsymbol{S p}=\{V m, L m, P r s\},
$$

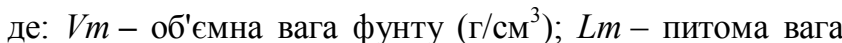

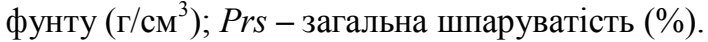

Множина типів фунтів $(S t)$ містить в собі підмножини генетичних горизонтів грунтів (Hor) механічного складу грунту $(M c h)$, агрохімічні властивості грунту $(C h)$ :

$$
\boldsymbol{S t}=\{\text { Hor, Mch, Ch }\} .
$$

$\mathrm{y}$ межах формування формалізованих описів генетичних горизонтів, прийнято позначати горизонти відповідними символами: основними (великі літери) та допоміжними (малі). Генетичні горизонти Hor є горизонтальними шарами, що якісно відрізняються один від одного. Перехідні зони позначаються назвами двох суміжних горизонтів. люють органічні речовини; $E$ - елювіальні, збіднені внаслідок вимивання; $I$ - ілювіальні, збагачені глинистими частинками внаслідок вимивання; $P$ - материнська порода.

$$
\boldsymbol{A}_{\text {hor }}=\{T H, T C, H d, P f, R, R g, S l, G l, M, D\},
$$

де: $T H$ - торф'яно-перегнійні, що складаються із сильно розкладених рослинних рештків; $T C$ - торф'яно-мінералізовані, що складаються переважно 3 напіврозкладених рослинних решток; $H d$ - дернові, що містять дернину; $P f$ - псевдофіброві, що складаються $з$ бурих або 
червонувато-бурих прошарків, що чергуються 3 прошарками піску; $R$ - ортзандові, що складаються з піску, зцементованого окислами заліза; $R g$ - ортштейнові, збагачені глиною, гелями кремнію; $S l$ - солонцеві, пептизована грунтова маса, збагачена рухомою глиною; $G l-$ глеєві, мінеральні або органо-мінеральні горизонти, що утворились у відновному середовищі; $M$ - мергелисті, що складаються $з$ карбонатних новоутворень гідрогенного походження; $D$ - порода, що залягає глибше, ніж материнська;

$\boldsymbol{A d}=\{k, s, r, n, k n, q, q k, f, z, d n, d l, d e, a l, a, a g, p l, m o, m\},(8)$ де: $k$ - наявність карбонатів; $s$ - наявність легкорозчинних солей; $r$ - наявність м'яких залізо-марганцевих стяжок; $n$ - наявність твердих залізо-марганцевих стяжок; $k n$ - наявність карбонатних конкрецій; $q$ - наявність уламків твердих безкарбонатних порід; $q k-$ наявність уламків твердих карбонатних порід; $f$ - охри; $z$ - наявність копролитів, кротовин; $d n$ - горизонти, що зазнали ерозії; $d l$ - делювіальні наносні горизонти на поверхні грунту; $d e$ - еолові наносні горизонти на поверхні грунту; $a l$ - алювіальні наносні горизонти на поверхні грунту; $a$ - орні горизонти; $a g$ - насипні (рекультивовані) горизонти; $p l$ - плантажовані горизонти; то - ознаки зрошення; $m$ - ознаки осушення.

Отже, якщо для визначення горизонту потрібно вказати його морфологічні особливості, то до визначення основного горизонту додається визначення морфологічних особливостей. Елементи підмножини $M c h$ умовно поділяють на такі класи: піски (зв'язні, супіски), суглинки (важкі, середні, легкі), глини (важкі, середні, легкі). Ці види механічного складу характеризуються гранулометричним складом:

$$
\boldsymbol{G r}=\{U l, C l y, S i\},
$$

де, за фракціями: $S i$ (пісок) $=\{1-0,5 ; 0,5-0,25 ; 0,25-$ $0,05\}$, мм; Cly (глина) $=\{0,05-0,01 ; 0,01-0,005 ; 0,005-$ $0,001\}$, мм; Ul (мул) $=\{<0,001\}$, мм.

Особливо важливими характеристиками грунту 3 погляду моделювання є множина агрохімічних характеристик:

$$
\begin{aligned}
& \boldsymbol{C h}=\left\{\mathrm{De}, p \mathrm{H}_{\mathrm{H} 2 \mathrm{O}}, \mathrm{pH}_{\mathrm{KCl}}, \mathrm{C}_{\text {op }}, \mathrm{Hum}, \mathrm{Ad}, \mathrm{Ca}, \mathrm{Mg}\right. \text {, } \\
& \mathrm{Ca}+\mathrm{Mg}, \mathrm{K}, \mathrm{P}, \mathrm{Na}, \mathrm{Hz}, \mathrm{Cp}, \mathrm{S}\},
\end{aligned}
$$

де: $D e-$ глибина відбору зразків (см); $\mathrm{pH}_{\mathrm{H} 2 \mathrm{O}}-\mathrm{pH}$ водний; $p H_{K C l}-\mathrm{pH}$ сольовий; $C_{\text {орг }}-$ вміст органічної речовини (\%); Нит - вміст гумусу (\%); $A d-$ поглинальна здатність грунту (мг-екв/100 г); вміст $\mathrm{Ca}, \mathrm{Ca}+\mathrm{Mg}, \mathrm{P}, \mathrm{K}$, $\mathrm{Na}$ (мг-екв/100 г); Hz - гідрологічна кислотність (мгекв/100 г фунту); $C p$ - ємність поглинання основ (мгекв/100 г фунту); $S$ - ступінь насиченості основами (\%).

У лісовій підстилці TD виділяють свіжий опад Frlf напіврозкладену $\mathrm{Hdlf}$ та розкладену лісову підстилку Dslf. 3 лісовою підстилкою пов'язують параметри, які характеризують кількість органічної речовини $C(\%)$, та гумусу Нит (\%).

При переході до формалізації описів видових характеристик лісової екосистеми зазначимо, що множину рослинності доцільно умовно поділити за ярусами Spf. Такий поділ зумовлений передусім тим, що під час моделювання міграції радіонуклідів, полютантів та седиментів доцільно виділяти міграцію не тільки між окремими складовими екосистеми, а і потоки біомас та переходи радіонуклідів, полютантів та седиментів між ярусами лісу.
$\boldsymbol{S p f}=\{\operatorname{Tr}, U g, U w$, Grb, Fal, Mos, Mush, Lch $\}$,

де: $\operatorname{Tr}$ - множина видів дерев; $U g$ - множина видів підліску; $U w$ - множина видів підросту; $G r b$ - множина видів трав'яно-чагарничкового ярусу; Fal - опад/відпад: множина відмерлих частинок органічної речовини з різних ярусів; Mos - множина видів мохового ярусу, Mush - множина видів грибів, Lch - множина видів лишайників.

Множину видів, що містяться в екосистемі цього виду, можна визначити двома способами: перерахуванням видів, що населяють цю територію; перетином множин ареалів видів з сусідніх едатопів.

Опис ярусу деревостою можна задати так:

$$
\boldsymbol{T r}=\{W d, B r k, S p r, N e d, L f, D r c h, R t\},
$$

де: $W d-$ стовбур; Brk- кора; Spr- пагони; Nedшпильки; $L f$ - листя; Drch - гілки; $R t$ - коріння.

3 ярусом $\boldsymbol{W d}$ пов'язані такі змінні, як: маса $\mathrm{mtr}$, висота $h t r$, середній діаметр - datr, вік - atr, зімкнутість $e d t r$, кількість дерев на одиницю площі - cntr.

$$
\boldsymbol{W d}=\{m t r, h t r, \text { datr, atr, edtr, cntr }\} .
$$

Кору Brk розрізняють зовнішню Brk_o та внутрішню $B r k \_i$ і пов'язують ії кількісно з масою окремих складових $m B r k i$, та загальною масою $m B r k$. Пагони $S p r$ розрізняють однорічні $S p r \_o$ та старші $S p r \_i$. Маси визначають як окремо $m S p r \_-\bar{o}$ та $m S p r \_i$, так і загалом $m S p r$. Шпильки Ned аналогічно, як і пагони, розрізняють однорічні Ned_o та старші Ned_i. Маси визначають як окремо $m N e d \_-o$ та $m N e d \_$, так і загалом $m N e d$. Листя $L f \epsilon$ однорічним, і з точки зору математичного моделювання важливою характеристикою для нього є маса $m L f$. Для відокремлення товстих гілок від тонких введено параметр діаметра гілок $d b c$. Вважатимемо, що гілки Brch завтовшки до 5 мм є тонкими, а якщо більше - товстими. Кількісною характеристикою для цього компартмента $\epsilon$ маса товстих $m b w$, тонких $m b t$ та загальна маса гілок $m b$. Подібно до опису гілок, для коріння $R t$ також встановлено межу, яка дає можливість розрізняти тонке та товсте коріння. Отже, за діаметра $d r$, меншого, ніж 2 мм, вважають коріння тонким, більшого ніж 2 ммтовстим. 3 точки зору математичного моделювання також необхідне задавання маси коріння як загалом $m r$, так і окремо для товстого та тонкого коріння $m r t$ та $m r w$ відповідно.

Для підросту та підліску формалізовані записи будуть подібними, за винятком того, що для цих ярусів не визначають кількість видових одиниць на одиницю площі. Тоді для підросту:

$$
\begin{gathered}
\boldsymbol{U} \boldsymbol{g}=\{W d g, \text { Brkg, Sprg, Nedg, Lfg, Brchg, Rtg }\} ; \\
\boldsymbol{W d g}=\{m g, h g, d g, a g, c d g\},
\end{gathered}
$$

а для підліску:

$\boldsymbol{U} \boldsymbol{w}=\{W d w, B r k w, S p r w, N e d w, L f w, B r c h w, R t w\} ;(17)$

$$
\boldsymbol{W d} \boldsymbol{w}=\{m w, h w, d w, a w, c d w\} .
$$

$\mathrm{Y}$ решті описів різниці між цими ярусами не зазначають.

Окремим компартментом виділяють опад та відпад, який описується фракційним складом Р2, оскільки потрапляє на поверхню фунту з різних ярусів.

$$
F r=\{\text { Brchf, Lff, Nedf, Budf }\},
$$

де $B r c h f$ - опалі бруньки. Опад та відпад пов'язують 3 однією змінною - біомасою $m f$ (кг/га). Такий детальний поділ на компартменти та зважування компартментів окремо дає змогу в подальшому не тільки оцінити дина- 
міку зміни біомаси, а й оцінити ступінь важливості цієї складової.

Для шару трав'яно-чагарничкових рослин $G r b$ виділяють надземну $O g$ та підземну $U g$ фітомасу, визначаючи їх маси $m o g$ та $m u g$ відповідно; глибину проникнення кореневої системи у грунт $d h r$. Для надземної фiтомаси визначають також проективне покриття $c d$ сумарне та для окремих видів, що входять до ярусу. Для підземної визначають глибину проникнення коріння $d r o t$.

Моховий ярус Mos під час математичного моделювання вважають компартментом, в якому виділяють живу $L_{m o s}$ та мертву $D_{m o s}$ частини:

$$
\boldsymbol{M o s}=\left\{L_{m o s}, D_{m o s}\right\} .
$$

Для кожної з частин визначають $\dddot{1 і ̈ ~ м а с у ~} m_{m o s}$ та проективне покриття $s p r$ :

$$
\begin{aligned}
& L_{\text {mos }}=\left\{m_{\text {mos }}, s p r\right\} ; \\
& D_{\text {mos }}=\left\{m_{\text {mos }}, s p r\right\} .
\end{aligned}
$$

Параметри $m_{m o s}, s p r$ пов'язані між собою, але 3 точки зору побудови математичної моделі вони характеризують моховий ярус з різних боків.

Серед грибів Mus виділяють мікоризоутворювачі, сапротрофи (гумусові та підстилкові), ксилотрофи (паразитні та сапротрофи). Серед мікоризних грибів розрізняють макроміцети та мікроміцети. Останні характерні для трав'яно-чагарничкового ярусу. Кількісною характеристикою, що описує ці види грибів, є маса висушеного плодового тіла $m_{b o d y}$. Загальна маса міцелію ттус визначається методом зважування висушених плодових тіл грибів з одиниці площі та множення на відповідний коефіцієнт $\mathrm{km}$. Цей коефіцієнт є визначеним тільки для мікоризоутворювачів $(\mathrm{km}=1: 154$ кг/га) та сапротрофів $(\mathrm{km}=1: 62,6$ кг/га), (Pogrebnjak, 1955). Ці коефіцієнти дають змогу визначити загальну масу міцелію за масою висушених плодових тіл. Загальна маса $m_{\text {mus }}=m_{\text {myc }}+m_{b o d y} \epsilon$ сумою міцелію та маси плодових тіл $m_{m y c}=m_{b o d y} \cdot \mathrm{km}$. Також важливо знати глибину проникнення міцелію в грунті $d_{m y c}$. Серед лишайників $L c h$ виділяють епігейні (що ростуть на грунті) та епіфітні (що ростуть на деревах). Епігейні лишайники не характерні для досліджуваного СЛК. Кількісною характеристикою, що описує ці два типи, є відношення біомаси до одиниці площі, на якій мешкають лишайники (кг/м² грунту).

Небезпеки для складних ландшафтних комплексів. Власне процес розвитку небезпеки можна описати такою логічною послідовністю: порушення екологічної стійкості $\rightarrow$ накопичення чинників, що призводять до відмов біологічних систем $\rightarrow$ реакція ярусів i/та підсистем компартментів на дію антропогенних чинників $\rightarrow$ синергія дії чинника $\rightarrow$ реакція на вражаючу дію.

У роботах (Zejliger \& Tamari, 1995; Jablokov \& Ostroumov, 1983) класифікацію антропогенних впливів на живу природу здійснено на основі концепції рівнів організації живої матерії. Розвиваючи цей підхід на основі ієрархічної структури СЛК, пропонуємо систему, яка впорядковує розмаїття ефектів, пов'язаних з антропогенним впливом на СЛК (таблиця).

Особливістю системи критеріїв, викладеної в таблиці, є зведення в чотири впорядкованих групи великої кількості антропогенних впливів на біоту. Антропогенні впливи поділяють відповідно до чотирьох рівнів по-

\begin{tabular}{|c|c|c|}
\hline $\begin{array}{l}\text { № } \\
\text { 3/ח }\end{array}$ & Рівень порушення & Приклади порушень і їх наслідків (деякі з них можуть належати до декількох рівнів) \\
\hline 1 & $\begin{array}{c}\text { Рівень індивідуальних і } \\
\text { популяційних відгуків }\end{array}$ & $\begin{array}{l}\text { - токсичні ефекти на окремі види організмів (збільшення смертності, зниження плодючості, по- } \\
\text { рушення онтогенезу, патології та ін.) }\end{array}$ \\
\hline 2 & $\begin{array}{l}\text { Рівень агрегованих (на- } \\
\text { дорганізмові) відгуків }\end{array}$ & $\begin{array}{l}\text { - зміна первинної продуктивності; зміна агрегованих показників біомаси; } \\
\text { - зміна концентрації хлорофілу у лісовій екосистемі; } \\
\text { - інші системні порушення, пов'язані з накопиченням важких металів та радіонуклідів } \\
\end{array}$ \\
\hline 3 & Рівень стійкості СЛК & $\begin{array}{l}\text { - перебудови і/або ослаблення зв'язків між грунтом } \rightarrow \text { моховим ярусом } \rightarrow \text { деревостаном } \rightarrow \text { під- } \\
\text { ростом, підліском, трав'яно-чагарниковим ярусом; } \\
\text { - перебудови і/або ослаблення зв'язків у трофічній мережі; } \\
\text { - зміна біогеохімічних циклів; } \\
\text { - слабка здатність до саморегуляції та самовідновлення; } \\
\text { - рівня бактеріальної деструкції зниження освітлення/вилучення часток з води зниження само- } \\
\text { очищення води; } \\
\text { - зниження регуляторних впливів під час випадання, догляду або трофічної пасивності організ- } \\
\text { мів вищих трофічних рівнів }\end{array}$ \\
\hline 4 & $\begin{array}{c}\text { Рівень вкладу СЛК в бі- } \\
\text { осферні процеси }\end{array}$ & $\begin{array}{l}\text { - зміна потоків (наприклад, седиментація полютантів), потоків } N \text { (наприклад, зміна рівня азот- } \\
\text { фіксації), потоків та циклів інших елементів, у тому числі } S \text { i } P \text {; } \\
\text { - зміна потоків енергії (теплової та ін.) }\end{array}$ \\
\hline
\end{tabular}
рушень біоти.

Таблиця. Концепція рівнеблокового підходу до аналізу екологічних небезпек антропогенного порушення біоти

Більшість традиційних токсичних ефектів (збільшення смертності, порушення онтогенезу та патології органів і т.ін.) потрапляє в групу, відповідну до рівня індивідуальних і популяційних відгуків (рівень 1). Ще одна група порушень та змін таких параметрів, як зміна первинної продуктивності; зміна агрегованих показників біомаси; зміна концентрації хлорофілу у лісовій екосистемі, інші системні порушення пов'язані з накопиченням важких металів та радіонуклідів (рівень 2). Дуже важливі і поки недостатньо охарактеризовані порушення, відносять до рівня стійкості та цілісності екосистем (рівень 3). Завершує цю систему група порушень вкладу екосистем у біосферні процеси (рівень 4), зокрема і в біогеохімічні потоки елементів.
Подібний підхід узгоджується 3 роботами інших авторів (Jablokov \& Ostroumov, 1985; Stroganov, 1976) i корисний під час розроблення максимально адекватної системи критеріїв і пріоритетів для оцінки і класифікації екологічної небезпеки антропогенних впливів, зокрема й екологічної небезпеки забруднювальних речовин. У запропонованій системі аналізу екологічної небезпеки належне місце займає небезпека впливу на стійкість і цілісність екосистеми, прикладом якої може слугувати небезпека ослаблення зв'язку між біотичними компонентами СЛК та абіотичними чинниками навколишнього середовища. Якщо антропогенний вплив послаблює цей зв'язок в екосистемі, то наслідки є несприятливими (Filenko, 1988). Отже, до опису складових СЛК мають бути введені змінні та параметри, що ха- 
рактеризують активність забруднювача в кожній складовій та щільність забруднення окремих складових.

Результати дослідження та їх обговорення. Отже, у загальному вигляді, опис лісової екосистеми, враховуючи концепцію рівнеблокового підходу до аналізу екологічних небезпек антропогенного порушення біоти $\boldsymbol{F}$, можна подати у такому вигляді:

$$
\boldsymbol{F}_{j i}=\left\{G_{i}, T_{j}, S_{p}, I, A m f, A s f\right\},
$$

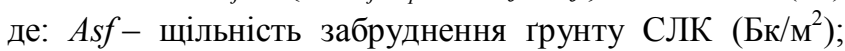
$A m f$ - питома актривність біомаси (Бк/кг).

Зважаючи на те, що трофотопи $T_{j}$ характеризуються множиною підмножин грунтових характеристик $S=$ $\{S p, S t, T D\}$, доцільно детальніше описати входження змінних, що характеризують активність забруднювачів, до множин характеристик грунту. Тоді формалізований опис агрофізичних властивостей $\boldsymbol{S p}$ грунту набуде вигляду

$$
\boldsymbol{S p}=\{V m, L m, \operatorname{Prs}, A m l\},
$$

де $A m l$ - питома активність, отримана переважно внаслідок лессіважу (Бк/кг). Для множини типів грунтів $\boldsymbol{S t}$ можна навести такий опис:

$$
\boldsymbol{S t}=\{\text { Hor, Mch, Ch, Amst, Asst }\},
$$

де: Amst - питома активність певного горизонту грунту (Бк/кг), Asst - щільність забруднення певного горизонту грунту $\left(Б \kappa / \mathrm{M}^{2}\right)$.

Зазначимо, що генетичні горизонти Hor відіграють провідну роль у міграції ${ }^{137} \mathrm{Cs}$. Гумусний горизонт є геохімічним бар'єром на шляху переходу радіонуклідів вглиб грунту. Механічний склад грунту $M c h$ впливає на мобільність радіонуклідів: наявність глинистих фракцій Cly сприяє міцній фіксації радіоцезію, але висока частка піщаної складової $S i$, навпаки, сприяє його міграції. Хімічні властивості грунту $C h$ істотно впливають на вертикальну та горизонтальну міграцію радіонуклідів у грунті. Кислі реакції, що відбуваються у грунті, сприяють збільшенню рухливості радіонуклідів та їх більшому надходженню у рослини.

Лісову підстилку TD більшість дослідників також вважає геохімічним бар'єром для ${ }^{137} \mathrm{Cs}$, що потрапляє на iii поверхню. Тому за середньої потужності 4-5 см підстилка із шпильок сосни, яка розкладається впродовж 6-8 років, здатна тривалий час утримувати радіонукліди у своїй товщі. Величиною, що характеризує накопичення підстилкою радіонуклідів, є $A m T D$ - питома активність (Бк/кг) як для всієї підстилки, так і за фракціями: свіжого опаду AmTlf напіврозкладеної Amdlf та розкладеної лісової підстилки Amslf.

Подібно до опису фітоценозу, що наведено вище, в проведених дослідженнях також всю множину видів фітоценозу можливо умовно поділити за ярусами і визначити питому активність ярусів $A m S p F$ для визначення міграції шкідливих речовин у межах ярусу та між ними: $\boldsymbol{S p f}=\{T r, U g, U w$, Grb, Fal, Mos, Mush, Lch, AmSpf. (26)

Опис ярусу деревостану можна задати так:

$$
\boldsymbol{T r}=\left\{W d, B r k, S p r, N e d, L f, B r c h, R t, A m_{-} s p f i\right\},
$$
де $A m \_s p f i$ - питома активність окремого виду дерева (Бк/кг). Так, для кожної фракції вводять питому активність, яка характеризує накопичення в ній, наприклад радіоцезію. Для компартмента $\boldsymbol{W d}$ :

$$
\boldsymbol{W d}=\{m t r, \text { htr, datr, atr, edtr, cntr, Amwd }\},
$$

де $A m w d$ - питома активність фракції деревини (Бк/кг).
Для підросту та підліску формалізовані записи будуть такими:

$\boldsymbol{U} \boldsymbol{g}=\{W d g$, Brkg, Sprg, Nedg, Lfg, Brchg, Rtg, Am_spgi $\},(29)$

$$
\boldsymbol{W d g}=\{m g, h g, d g, a g, c d g, A m g\},
$$

$\boldsymbol{U} \boldsymbol{w}=\left\{W d w, B r k w, S p r w, N e d w, L f w, B r c h w, R t w, A m \_s p w i\right\},(31)$

$$
\boldsymbol{W d} \boldsymbol{w}=\{m w, h w, d w, a w, c d w, A m w d\},
$$

де: $A m_{-} s p g i-$ питома активність окремого виду підросту (Бк/кг); Amg - питома активність фракції стовбуру підросту (Бк/кг); Аm_spwi-nuтома активність окремого виду підліску (Бк/кг); Атwd - питома активність стовбуру підліску (Бк/кг).

У решті описів різниці між цими ярусами можна не зазначати. Накопичення полютантів та седиментів для кожної фракції розраховують аналогічно. Для опаду та відпаду визначають питому активність фракцій окремо $A m \_l f i$, що дає змогу кількісно оцінити динаміку переходу радіонуклідів, полютантів та седиментів з одного компартмента в інший. Для ярусу трав'яно-чагарничкових рослин $G r b$ вимірюють питому активність надземної $\mathrm{AmOg}$ та підземної $\mathrm{AmUg}$ фітомаси. Середньозважені ці показники для всього ярусу, або для кожного конкретного виду. Оскільки моховий ярус Mos під час математичного моделювання вважають компартментом, в якому виділяється жива $L_{m o s}$ та мертва $D_{m o s}$ частини, то визначається окремо питома активність кожної частини $A m L m$, та $A m D m$ середньозважені ці показників для всього ярусу або для кожного конкретного виду. Для грибів Mus вважають, що питома активність плодових тіл $A m_{b o d y}$ дорівнює питомій активності міцелію $\mathrm{Aт}_{\text {тус }}$ (Ostroumov, Donkin \& Staff, 1997; Kaurichev et al., 1982). Для лишайників Lch також визначають питому активність Amlch, яка характеризує вміст радіонукліду в цьому компартменті лісової екосистеми.

Висновки. Система критеріїв, наведена в таблиці, спрощує і впорядковує аналіз екологічної ролі та наслідків порушення конкретної фізіологічної функції. Переходячи в запропонованій системі від рівня до рівня, зручно простежувати масштабування екологічних наслідків порушення, на рівні особин, але здатного проявити себе в екологічно небезпечній формі на інших рівнях організації СЛК.

\section{Перелік використаних джерел}

Bezel, B. C., Bolshakov, V. N., \& Vorobejnik, E. L. (1994). Populjacionnaja jekotoksikologija. Moscow: Nauka, 81 p. [In Russian].

Filenko, O. F. (1988). Vodnaja toksikologija. Chernogolovka: Publishing MGU, 156 p. [In Russian].

Filenko, O. F. (1988). Vodnaja toksikologija. Chernogolovka: Publishing MGU, $156 \mathrm{p}$. [In Russian].

Flerov, B. A. (1989). Jekologo-fiziologicheskie aspekty toksikologii presnovodnyh zhivotnyh. Leningrad: Nauka, 144 p. [In Russian].

Jablokov, A. V., \& Ostroumov, S. A. (1983). Ohrana prirody: problemy i perspektivy. Moscow: Lespromizdat, 272 p. [In Russian].

Jablokov, A. V., \& Ostroumov, S. A. (1985). Urovni ohrany zhivoj prirody. Moscow: Science, 176 p. [In Russian].

Kaurichev, I. S., Aleksandrova, L. N., Panov, N. P., et al. (1982). Pochvovedenie. Moscow: Kolos, 496 p. [In Russian].

Krivoluckij, D. A. (1994). Pochvennaja fauna v jekotoksiko-logicheskom kontrole. Moscow: Nauka, 272 p. [In Russian].

Li, B.-L., Gorshkov, V. G., Makarieva, A. M., \& Petrosillo, I., et al. (Eds). (2008). Allometric scaling as an indicator of ecosystem state: a new approach. Use of Landscape Sciences for the Assessment of Environmental Security, NATO Science for Peace and Security Series C: Environmental Security, Springer, the Netherlands, 107117. 
Malahov, V. V., \& Medvedeva, L. A. (1991). Jembrional'noe razvitie dvustvorchatyh molljuskov $v$ norme i pri vozdejstvii tjazhelyh metallov. Moscow: Science, 132 p. [In Russian].

Obshta, A., Bubela, T., Ruda, M., \& Kochan, R. (2018). The model of environmental assessment of complex landscape systems. Renewable energy sources and clean technologies: Proceedings 18th International Multidisciplinary Scientific GeoConference, July 2-8, 2018, (pp. 973-979). Albena, Bulgaria.

Ostroumov, S. A. (1986). Vvedenie v biohimicheskuju jekologiju. Moscow: Publishing MGU, 176 p. [In Russian].

Ostroumov, S. A., Donkin, P., \& Staff, F. (1997). MGU. Ser. 16. Biologija, 3, 30-36. [In Russian].

Pogrebnjak, P. S. (1955). Osnovy lesnoj tipologii. Kyiv: Publishing AN USSR, 456 p. [In Russian]
Ruda, M., Paslavskyi, M., \& Taras, Y. (2018). Scientific development and achievements. London: SCIEMCEE Publishing London, $402 \mathrm{p}$.

Stroganov, N. S. (1976). Obshhaja jekologija. Biocenologija. Gidrobiologija. Vodnaja jekologija. (Vol. 3, pp. 5-47). Moscow: VINITI. [In Russian].

Telitchenko, M. M., \& Ostroumov, S. A. (1990). Vvedenie v problemy biohimicheskoj jekologii. Moscow: Science, 288 p. [In Russian].

Yablokov, A., V., \& Ostroumov, S. A. (1991). Conservation of Living Nature and Resources: Problems, Trends and Prospects. B.: Springer, 272 p. https://doi.org/10.1007/978-3-642-75376-3

Zejliger, A. M., \& Tamari, S. (1995). Sposoby formal'nogo predstavlenija gidrofizicheskih harakteristik vodouderzhivanija i vlagoprovodnosti pochvju. Pochvovedenie, 2, 192-199. [In Russian].

T. Gh. Bojko', M. M. Paslavskyi', M. V. Ruda ${ }^{1}$

${ }^{1}$ Lviv Polytechnic National University, Lviv, Ukraine

${ }^{2}$ Ukrainian National Forestry University, Lviv, Ukraine

\section{STABILITY OF COMPOSITE LANDSCAPE COMPLEXES: MODEL FORMALIZATION}

The concept of "sustainability" for the composite landscape complex is defined in the paper. The logical sequence of the risk development process in a landscape complex is described. A system of criteria has been developed based on the subdivision of a large number of anthropogenic impacts on biota into four orderly groups. Anthropogenic impacts are categorised according to four levels of impaired biota. Most of the traditional toxic effects (increased mortality, disorders of ontogenesis and pathology of the organs, etc.) belong to the group corresponding to the level of individual and population responses (level 1). Another group of disorders and change parameters contains the following: change in primary productivity, change in aggregate indicators of biomass, change in the concentration of chlorophyll in the forest ecosystem, and other systemic disorders associated with accumulation of heavy metals and radionuclides (level 2). Very important yet under-described violations relate to the level of sustainability and integrity of ecosystems (level 3). The group of violations of the contribution of ecosystems to biosphere processes (level 4) including biogeochemical flows of elements completes this system. The approach presented is useful in the development of the most adequate system of criteria and priorities to assess and classify ecological risk of anthropogenic impacts including ecological danger of pollutants. In the proposed system of environmental hazard analysis, due place occupies a risk of affecting the stability and integrity of ecosystems, an example of which can serve as a risk of weakening of relationships between biotic components of a composite landscape complex and abiotic environmental factors. If an anthropogenic effect weakens this relationship in the ecosystem, the consequences can be unfavourable. Thus, the description of the CLC components should contain input variables and parameters characterizing the activity of the pollutant in each component and the density of contamination of individual components. The description of forest ecosystems considers the concept of runeblades approach to the analysis of ecological hazards of anthropogenic disturbances on biota. The system of criteria simplifies and streamlines the analysis of the ecological role and consequences of violations of specific physiological functions. Turning to the proposed system from level to level, it is convenient to trace the scale of the environmental effects of violations on an individual level, but is able to express themselves in an ecologically hazardous form at other levels of organization of landscapes complex.

Keywords: sustainability; landscape complex; model; compartment; multiple; system. 